\title{
Implication of Egr-1 in trifluoperazine-induced growth inhibition in human U87MG glioma cells
}

\author{
Soon Young Shin ${ }^{1}$, Chang Gun $\mathrm{Kim}^{2}$, \\ Dong Dae Hong ${ }^{3}$, Jung-Hye $\mathrm{Kim}^{3}$ \\ and Young Han Lee $e^{2,4}$ \\ ${ }^{1}$ Institute of Natural Science and Technology \\ ${ }^{2}$ Division of Molecular and Life Science \\ College of Science and Technology \\ Hanyang University, Ansan \\ Gyeonggi-do 426-791, South Korea \\ ${ }^{3}$ Department of Biochemistry and Molecular Biology \\ College of Medicine, Yeungnam University \\ Daegu 705-717, South Korea \\ ${ }^{4}$ Corresponding author: Tel, 82-31-400-5517; \\ Fax, 82-31-416-9781; E-mail, younghan@hanyang.ac.kr
}

Accepted 4 August 2004

Abbreviations: TFP, trifluoperazine

\begin{abstract}
The early growth response gene-1 (Egr-1) is a tumor suppressor which plays an important role in cell growth, differentiation and apoptosis. Egr-1 has been shown to be down-regulated in many types of tumor tissues. Trifluoperazine (TFP), a phenothiazine class of antipsychotics, restored serum-induced Egr-1 expression in several cancer cell lines. We investigated the effect of Egr-1 expression on the TFP-induced inhibition of cell growth. Ectopic expression of Egr-1 enhanced the TFP-induced antiproliferative activity and downregulated cyclin D1 level in U87MG glioma cells. Our results suggest that antipsychotics TFP exhibits antiproliferative activity through up-regulation of Egr-1.
\end{abstract}

Keywords: cell cycle; cyclin D1; glioma; trifluoperazine; tumor suppressor proteins

\section{Introduction}

Early growth response-1 (Egr-1) gene, which is also known as NGFI-A, zif268, krox24 or Tis8 (Lim et al., 1987; Milbrandt, 1987; LeMaire et al., 1988; Christy et al., 1989), encodes a nuclear protein that has three
Cys2-His2 type zinc finger-containing DNA-binding domains in the $\mathrm{C}$-terminal portion of the molecule (Sukhatme et al., 1988). Egr-1 preferentially binds to GC-rich regulatory elements, leading to the induction or repression of its target genes (Lim et al., 1987; Christy et al., 1989). Egr-1 is rapidly induced by a broad spectrum of extracellular signals including nerve growth factor, depolarization, ischemic injury, and differentiation stimuli Tis8 (Gilman et al., 1986; Lim et al., 1987; Milbrandt, 1987; LeMaire et al., 1988; Sukhatme et al., 1988; Christy et al., 1989), implicating Egr-1 as an important mediator in cell growth, differentiation, and cell survival. Egr-1 expression is absent or reduced in a number of tumor cells (Huang et al., 1995; Levin et al., 1995; Huang et al., 1997) and in PLC Y1-transformed $3 Y 1$ fibroblasts (Shin et al., 2002a). Stable expression of Egr-1 inhibited cell proliferation and soft-agar growth in NIH3T3 cells transformed with $v$-sis (Huang et al., 1995), suggesting that loss of Egr-1 expression is closely associated with tumor formation.

Trifluoperazine (TFP) is a phenothiazine derivative and a commonly used antipsychotic drug. The clinical potency of phenothiazines may be related to a blockade of the dopamine receptor (Snyder, 1974). In addition to its therapeutic effects, TFP is also widely used as a calmodulin antagonist (Weiss et al., 1978; Osborn et al., 1980). TFP binds to calmodulin and interferes with $\mathrm{Ca}^{2+}$-calmodulin interactions, and thereby blocks $\mathrm{Ca}^{2+}$-calmodulin dependent cellular events. Calmodulin is a $\mathrm{Ca}^{2+}$-bining protein, which is ubiquitously expressed in almost eukaryotic cells (Cheung et al., 1980 ) and plays a key role in mediating $\mathrm{Ca}^{2+}$-dependent diverse physiological responses including regulation of cell proliferation (Means et al., 1980; Lu et al., 1993; Schulman, 1993). It has been reported that calmodulin antagonists inhibit cell proliferation in several types of cancer cells (Hidaka et al., 1981; Hait et al., 1985). Previously, we have reported that calmodulin antagonist TFP induces apoptotic cell death in rat PC12 cells (Kang et al., 1999) and TFP stimulates Egr-1 gene expression by modulating Rasdependent Elk-1 activity in human HT1080 fibrosarcoma cells (Shin et al., 2001). However, the functional role of Egr-1 induced by TFP has not been fully elucidated. The aim of this study was to investigate the role of TFP-mediated Egr-1 expression on the tumor cell growth. 


\section{Materials and Methods}

\section{DNA synthesis assay}

Effect of TFP on the DNA synthesis was measured by $\left[{ }^{3} \mathrm{H}\right]$-methyl-thymidine incorporation. Cells were cultured in 24-well plates in the presence of increasing concentrations of TFP. After $24 \mathrm{~h}$ of TFP treatment, $\left[{ }^{3} \mathrm{H}\right]$-methyl-thymidine $(247.9 \mathrm{GBq} / \mathrm{mmol}$. NEN) was added at $0.2 \mu \mathrm{Ci} /$ well for $4 \mathrm{~h}$. Cells were then washed with PBS, and precipitated with 15\% trichloroacetic acid. The acid-insoluble materials were washed with ether:methanol $(2: 1)$, solubilized with $0.4 \mathrm{M} \mathrm{NaOH}$ for $2 \mathrm{~h}$ at $4^{\circ} \mathrm{C}$, and then the radioactivity was counted with a liquid scintillation $\beta$-ray counter.

\section{Cell proliferation assay}

Cells were seeded at a density of $1 \times 10^{5}$ cells in a $35-\mathrm{mm}$ culture dish and counted in triplicate at 12-h intervals after plating. The viability of cells was estimated by the dye exclusion method after staining with $0.4 \%$ trypan blue staining.

\section{FACS analysis}

Cells were treated with $20 \mathrm{M}$ TFP for $24 \mathrm{~h}$. The cells were collected and fixed in $70 \%$ ethanol. The fixed cells were washed twice with PBS, and stained with $50 \mu \mathrm{g} / \mathrm{ml}$ propidium iodide solution containing $0.1 \%$ Triton X-100, $0.1 \mathrm{mM}$ EDTA, and $50 \mu \mathrm{g} / \mathrm{ml}$ RNase A. The propidium iodide stained cells were analyzed at $488 \mathrm{~nm}$ using FACScan flow cytometer (Becton Dickson Corp).

\section{Western blot analysis}

Cells were lysed in $20 \mathrm{mM}$ HEPES, pH 7.2, 1\% Triton $\mathrm{X}-100,10 \%$ glycerol, $150 \mathrm{mM} \mathrm{NaCl}, 10 \mu \mathrm{g} / \mathrm{ml}$ leupeptin, and $1 \mathrm{mM}$ PMSF. Protein samples $(20 \mu \mathrm{g}$ of each) were separated by SDS-PAGE $(10 \%)$ and transferred to nitrocellulose filters (Shin et al., $2002 b)$. The blots were incubated with anti-Egr-1 antibodies and developed with the enhanced chemiluminescence detection system (Amersham Pharmacia Biotech., Piscataway, NJ). The same blot was reprobed with anti-Erk1/2 antibody for use as an internal control.

\section{Egr-1 promoter assay}

U87MG cells were grown in DMEM with $10 \%$ heatinactivated fetal calf serum. One day after seeding cells into $35-\mathrm{mm}$ dishes $\left(6 \times 10^{5}\right.$ cells), the cells were co-transfected with $0.5 \mu \mathrm{g}$ of $5^{\prime}$ deletion constructs of the Egr-1 promoter (Shin et al., 2001) and $0.2 \mu \mathrm{g}$ of pCMV/ $\beta$-gal plasmid using Lipofectamine 2000 reagents (Life Technologies) according to the manu- facturer instructions. At $24 \mathrm{~h}$ post transfection, cells were treated with TFP. Cells were harvested after 6 to $12 \mathrm{~h}$ of TFP treatment and protein extracts were prepared by three cycles of freezing and thawing. One to five $\mu \mathrm{g}$ of protein was assayed for luciferase activities. Luminiscence was measured using a luminometer model TD 2020 (Berthold, Tubingen, Germany).

\section{Results and Discussion}

Restoration of Egr-1 expression by combined treatment with TFP and serum. Previously, we have found that Egr-1 is substantially induced by phorbol myristate acetate (PMA) but not by serum in HT1080 fibrosarcoma cells (Shin et al., 2001). This suppression was recovered by combined treatment with TFP and serum (Figure 1, upper left). In this study we investigated whether the effect of combined treatment with serum and TFP on the stimulation of Egr-1 expression is a general phenomenon. U87MG human glioma cells were serum-deprived for $24 \mathrm{~h}$ and then treated with $20 \%$ serum in the absence or presence of TFP. PMA was used as a positive control. Treatment with serum alone failed to stimulate the induction of Egr-1, however, co-stimulation with serum plus TFP strongly accumulated Egr-1 protein (Figure 1, upper

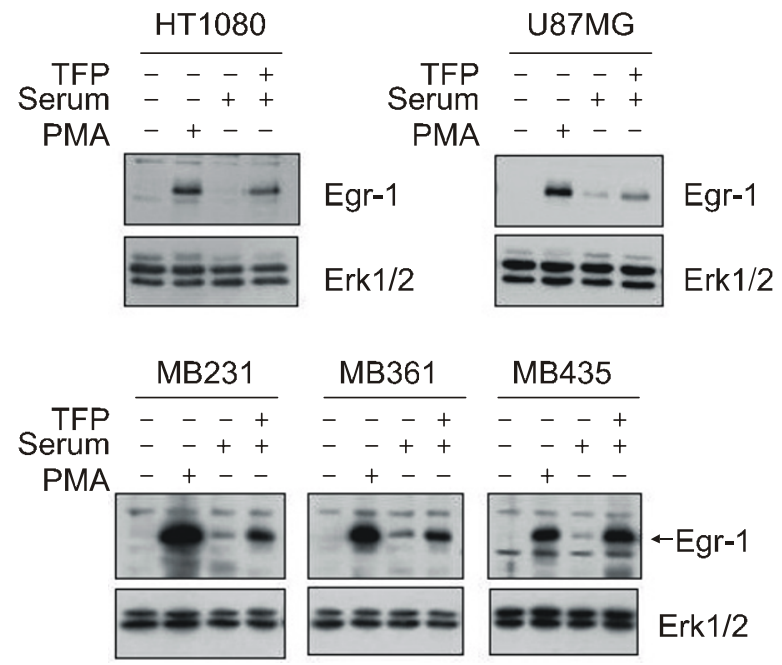

Figure 1. Effect of TFP on the accumulation of Egr-1 protein. Tumor cells starved with $0.5 \%$ serum for $24 \mathrm{~h}$ were pretreated with TFP $(20 \mu \mathrm{M})$ for $30 \mathrm{~min}$ before addition of $20 \%$ serum. PMA (50 nM) was used as a positive control. After $2 \mathrm{~h}$, the amount of Egr-1 protein was detected in whole cell lysates $(20 \mu \mathrm{g})$ by Western blotting using rabbit anti-Egr-1 antibody (1:1000). The same blot stripped and reprobed with rabbit anti-Erk1/2 antibodies for an internal control of the protein. 
right). TFP alone slightly increased the level of Egr-1 protein (data not shown). Similar results were obtained in breast cancer cell lines including MDA-MB 231, -MB 361 and -MB 435 (Figure 1, bottom). The results demonstrate that TFP restores Egr-1 expression, at least, in fibrosarcoma, glioma and breast carcinoma cells.

\section{Effect of TFP on the Egr-1 promoter activity in U87MG glioma cells}

To determine whether TFP-mediated induction of Egr-1 occurred at the transcriptional level, U87MG cells were transfected with serial deletion constructs of Egr-1 promoter, $p$-688egrLuc, p-454egrLuc and $\mathrm{p}$-233egrLuc (Figure 2A), and treated with TFP at a concentration of $30 \mu \mathrm{M}$. PMA was used as a positive control. Results were expressed as a fold-increase in luciferase activity normalized for $\beta$-galactosidase acti-

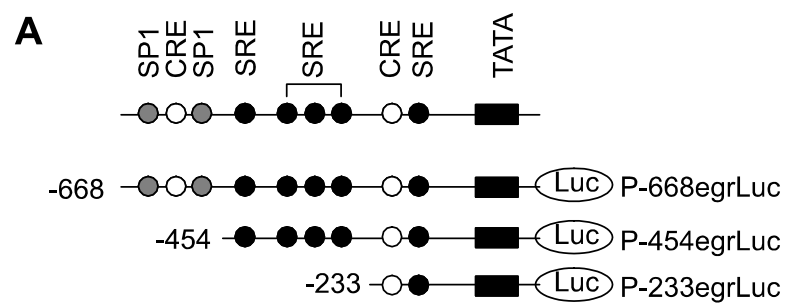

B

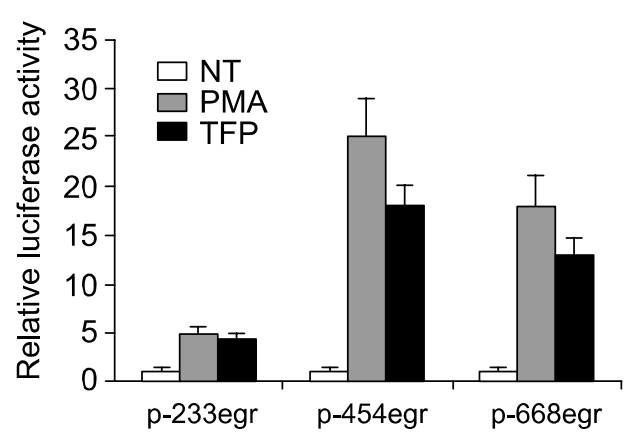

Figure 2. Effect of TFP on human Egr-1 promoter activity. (A) The 5 ' boundaries of plasmids containing various truncations of the Egr-1 promoter fused to luciferase reporter gene. The numeric designations of each construct refer to the $5^{\prime}$ deletion endpoints derived from the transcription start site at +1 . The positions of putative regulatory elements (SP1, CRE, and SRE) are indicated by circles. (B) U87MG cells cultured on $35-\mathrm{mm}$ dishes were co-transfected with each construct of the Egr-1 promoter $(0.5 \mathrm{mg})$ and the $\mathrm{pCMV} / \beta$-gal plasmid $(0.2 \mu \mathrm{g})$. After $24 \mathrm{~h}$ of transfection, cells were treated without (NT) or with TFP $(50 \mu \mathrm{M})$. PMA $(50 \mathrm{nM})$ was used as a positive control. Cells were harvested after an additional incubation for $12 \mathrm{~h}$ and protein extracts were prepared by three cycles of freezing and thawing. One $\mathrm{mg}$ of protein was assayed for luciferase and $\beta$-galactosidase activities. Results are shown as the amount of induction after correcting for $\beta$-galactosidase activity. Error bars represent SD from three independent experiments in duplicate.
A

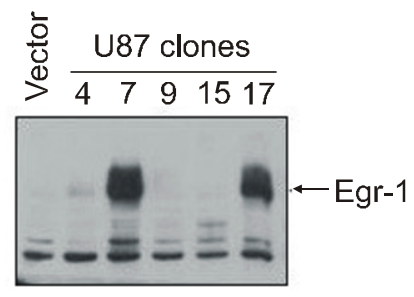

B

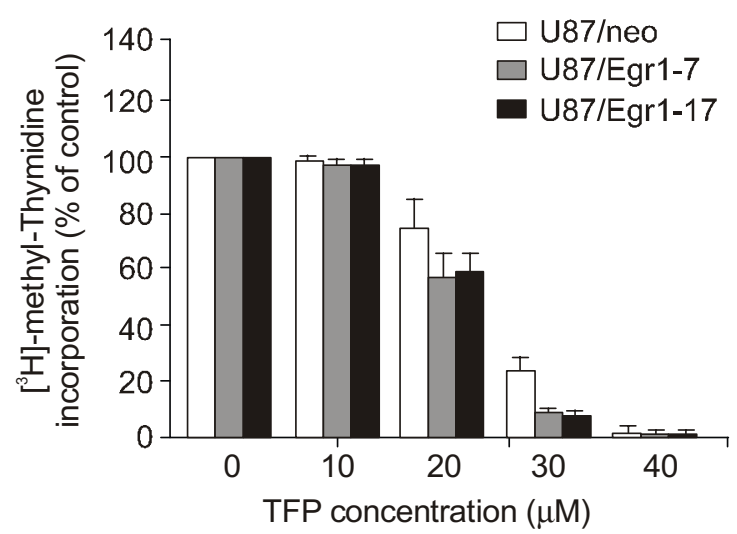

C

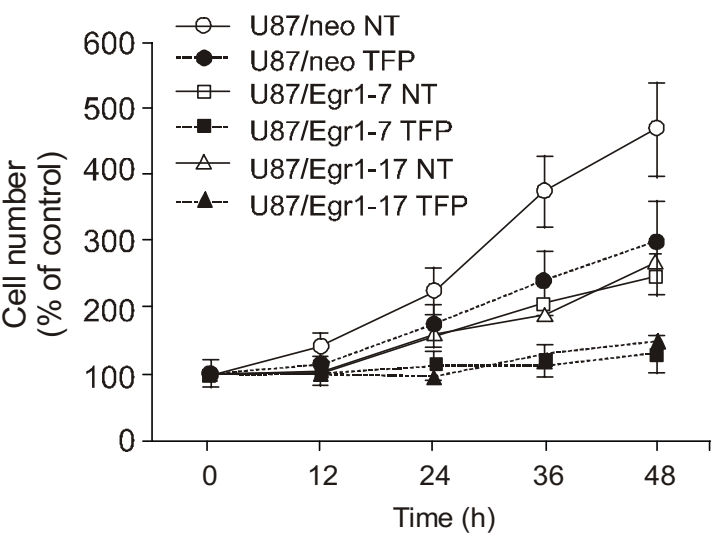

Figure 3. Effect of ectopic expression of Egr-1 on the TFP-induced growth inhibition. (A) U87MG cells maintained in $100-\mathrm{mm}$ culture dish were transfected with an expression vector $(30 \mu \mathrm{g})$ containing Egr-1 cDNA (pCMVtag2B/Egr-1) or lacking the insert ( $\mathrm{pCMVtag} 2 \mathrm{~B} /$ neo). After selection with $0.7 \mathrm{mg} / \mathrm{ml}$ of geneticin (G418), Egr-1 expression was analyzed by Western blotting. (B) U87MG transfectants cultured in 24-well plates in the presence of increasing concentrations of TFP were pulse labeled for $1 \mathrm{~h}$ with $0.2 \mu \mathrm{Ci} /$ well of $\left[{ }^{3} \mathrm{H}\right]$ thymidine. After precipitation with $15 \%$ trichloroacetic acid, radioactivity incorporated into the acid-insoluble material was measured with a liquid scintillation $\beta$-ray counter. Error bars represents SD from two independent experiments in triplicate. (C) U87MG transfectants were seeded into $35-\mathrm{mm}$ culture dishes and treated with TFP at $20 \mu \mathrm{M}$. Every $12 \mathrm{~h}$, the viable cell number was determined by the dye exclusion method after staining with $0.4 \%$ trypan blue. Error bars represents SD from two independent experiments in triplicate. 
vity. The -668 and -454 constructs exhibited a 28and 18-fold increase of luciferase activity, respectively, due to the addition of TFP, indicating that TFP stimulates Egr-1 gene expression at the transcription level (Figure 2B).

\section{Effect of ectopic expression of Egr-1 on the cell growth in U87MG glioma cells}

To determine the functional role of Egr-1 expression by TFP, U87MG cells were stably transfected with an expression vector containing Egr-1 cDNA (pCMVtag2B/Egr-1) or lacking the insert (pCMVtag2B/neo). Three weeks after transfection, G418 resistant clones were selected and the elevated level of exogenous Egr-1 was detected by Western blot analysis. From them, we used clone 7 (U87/Egr1-7) and clone 17 (U87/Egr1-17) for the next experiments (Figure 3A). Empty vector-transfected cells (U87/neo) were used as a control. The effect of exogenous expression of Egr-1 on the growth response was assessed by $\left[{ }^{3} \mathrm{H}\right]-$ methyl-thymidine incorporation into DNA (Figure 3B). Treatment with TFP reduced $\left[{ }^{3} \mathrm{H}\right]$ methyl-thymidine incorporation in a concentration-dependent fashion. In U87/neo cells, $\left[{ }^{3} \mathrm{H}\right]$ methyl-thymidine uptake after treatment with TFP at $20 \mu \mathrm{M}$ or $30 \mu \mathrm{M}$ was reduced to $75 \%$ or $25 \%$, respectively, of that observed in vehicle-treated cells. In contrast, in U87/Egr1 transfectants, $\left[{ }^{3} \mathrm{H}\right]$ methyl-thymidine uptake after treatment with TFP at $20 \mu \mathrm{M}$ or $30 \mu \mathrm{M}$ was reduced to $58 \%$ or $25 \%$ of that observed in vehicle-treated cells. A complete inhibition resulted when all the U87MG tranfectants were treated with TFP at $40 \mu \mathrm{M}$. Cell proliferation as measured by counting of viable cells was also inhibited by treatment with TFP at $20 \mu \mathrm{M}$ (Figure 3C). U87/neo cells showed about a $470 \%$ increase of cell numbers in the absence of TFP, whereas about a $300 \%$ increase in the presence of TFP after $48 \mathrm{~h}$ of incubation. Compared to U87/neo cells, there was a considerable decrease in cell proliferation in U87/Egr1 transfectants, indicating that forced expression of Egr-1 leads to more sensitive to TFP-inducible inhibition of cell growth. These results suggest that the Egr-1 induction by TFP is required for TFP-inducible antiproliferative activity in U87MG glioma cells.

\section{Effect of TFP and Egr-1 expression on the cell cycle distribution}

To determine the possible mechanism involved in the growth inhibition by TFP-induced Egr-1, the progression of cell cycle was determined by a FACS (Figure 4). In U87/Egr1 transfectants, the numbers of cells increased in the Go/G1 phase $(63.08 \%$ versus $82.4 \%)$ but decreased in $S(9.25 \%$ versus $4.3 \%)$ and $\mathrm{G} 2 / \mathrm{M}$ $(27.76 \%$ versus $13.34 \%)$ phase of the cell cycle as compared to U87/neo cells (first low panels). Treatment with TFP for $24 \mathrm{~h}$ increased $\mathrm{G} 1$ populations both in U87/neo (from $63.08 \%$ to $74.35 \%$ ) and in U87/Egr1-17 cells (from $82.4 \%$ to $87.04 \%$ ) but decreased in the cell populations both in the $S$ phase
U87/neo
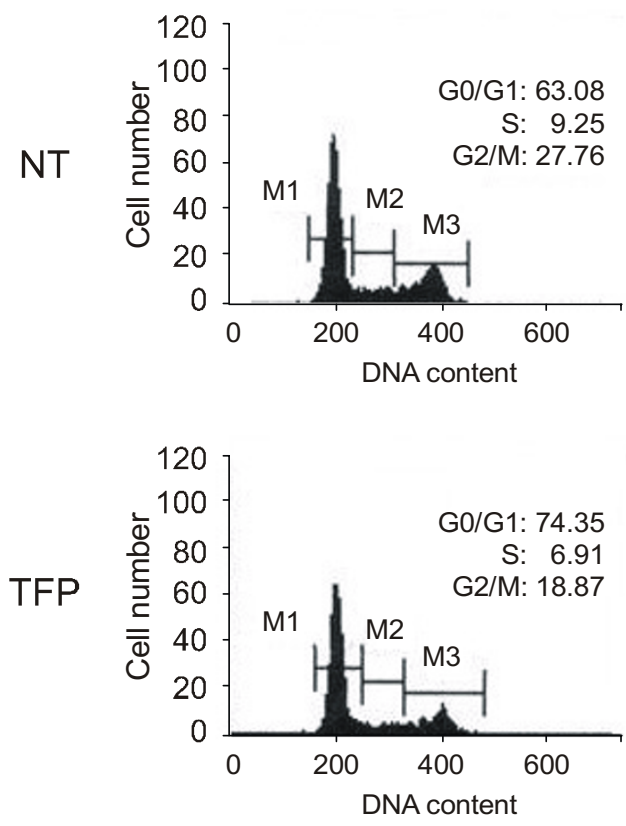

U87/Egr1-17
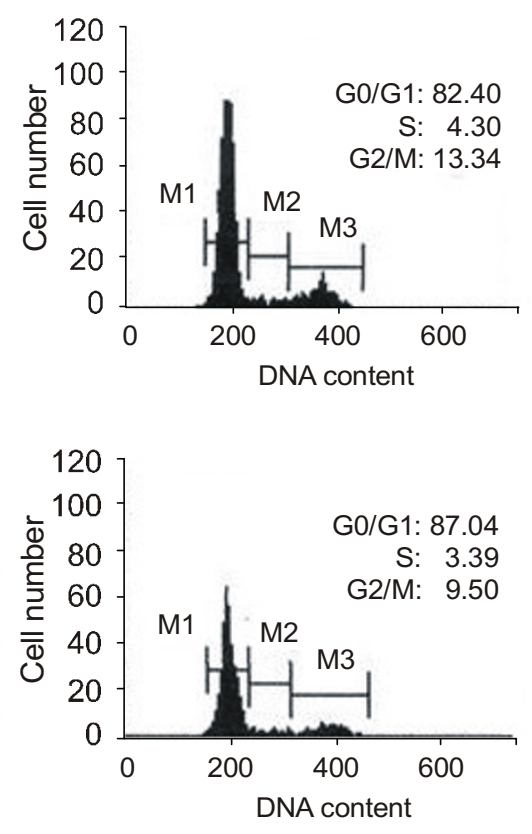

Figure 4. Effect of ectopic expression of Egr-1 on the cell cycle distribution. U87MG transfectants treated with 20 $\mu \mathrm{M}$ TFP for $24 \mathrm{~h}$. DNA content was analyzed by propidium iodide staining at $488 \mathrm{~nm}$ using FACScan flow cytometer. Similar results were obtained from two independent experiments. 
(from $9.25 \%$ to $6.91 \%$ in U $87 /$ neo, and from $4.3 \%$ to $3.39 \%$ in U87/ Egr1-17) and G2/M phase (from $27.76 \%$ to $18.87 \%$ in U87/neo, from $13.34 \%$ to $9.5 \%$ in U87/Egr1-17) (second row panels). These data suggest that TFP-mediated Egr-1 expression contributes to the inhibition of cell cycle progression.

\section{Effect of ectopic expression of Egr-1 on the cyclin D1 expression}

We next analyzed the effect of ectopic expression of Egr-1 on the expression of cell cycle regulators by Western blotting. We found that steady-state level of cyclin D1 protein was decreased in U87/Egr1-17 cells as compared to that in U87/neo cells, whereas cyclin $E$, cyclin $A 1$ and PCNA were not changed (Figure

A

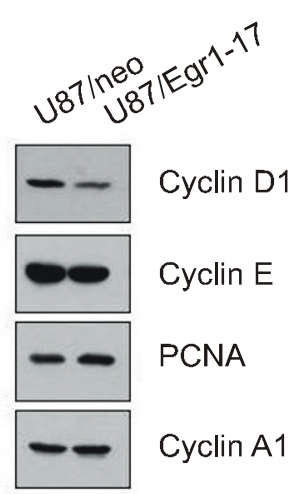

B

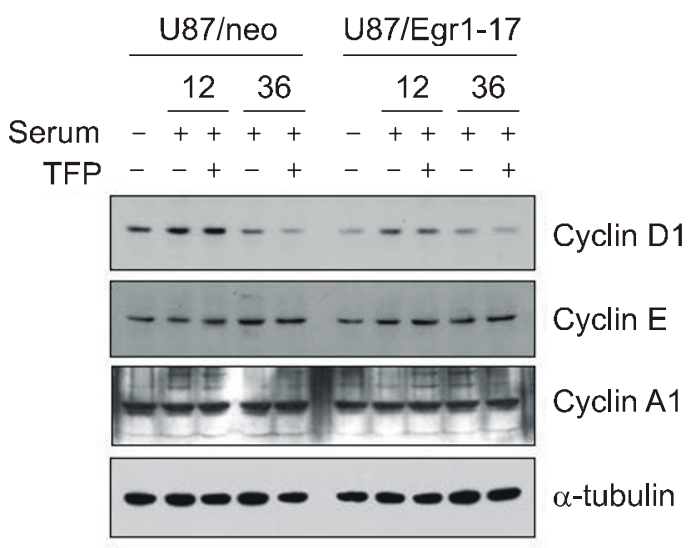

Figure 5. Effect of ectopic expression of Egr-1 on the accumulation of cyclin D1. (A) Exponentially growing U87MG transfectants were harvested and whole lysates $(20 \mu \mathrm{g})$ were used for Western blot analysis using anti-cyclin D1, -PCNA, and -cyclin A1 antibodies. (B) Serum-starved U87MG transfectants were pretreated or not with 20 $\mu \mathrm{M}$ TFP for $30 \mathrm{~min}$, then stimulated or not with $20 \%$ serum for indicated times. Whole lysates $(20 \mathrm{mg})$ were subjected to Western blotting using anti-cyclin D1 or anti-cyclin E antibody. The same blot was reprobed with anti- $\alpha$-tubulin antibody for internal control. Similar result was obtained from two independent experiments.
$5 A)$. Since expression of cyclin $D 1$ is a prerequisite for G1-to-S phase transition, we investigated whether TFP treatment influences the accumulation of cyclin D1 protein (Figure 5B). When serum-starved cells were treated with $20 \%$ serum in the absence or presence of $20 \mu \mathrm{M}$ of TFP, the amount of cyclin D1, but not cyclin $E$ and cyclin $A 1$, was considerably decreased in U87/Egr1-17 cells. Because the transition of cells from $G 1$ to $S$ phase of cell cycle is in part regulated by cyclin D1, it seems likely that Egr1 -induced anti-proliferative activity in U87MG cells is mediated by downregulation of cyclin D1, at least in part. Taken together, our results suggest that TFP controls Egr-1 expression, which in turn leads to a blockade of G1 cell cycle progression and an inhibition of cell proliferation.

It has been reported that introduction of Egr-1 gene into HT1080 fibrosarcoma cells inhibits tumorigenic potential by induction of transforming growth factor- $\beta 1$ (TGF-ß1), fibronectin, and plaminogne activator inhibitor-1 (PAI-1) (Liu et al., 1996; 1999). Egr-1 also directly transactivates tumor suppressor gene promoters including PTEN/MMAC1/TEP1 gene (Virolle et al., 2001) and p53 gene (Nair et al., 1997; Das et al., 2001; Krones-Herzig et al., 2003), implicating the role of Egr-1 in the regulation of cell death and growth context. Thus, suppression of Egr-1 expression may be the crucial event in the development of malignant transformation. In the present study, we show that Egr-1 expression is suppressed in diverse cancer cell lines, including fibrosarcoma (HT1080), breast carcinoma (MDA MB-231, MDA MB-361, MDA MB-435) and glioma (U87MG) cell lines. This is consistent with a growing body of evidence indicating a role for the Egr-1 gene in the tumor suppressor function. We found that calmodulin antagonist TFP restores Egr-1 expression at the transcriptional level in U87MG glioma cells, and that ectopic expression of Egr-1 in U87 MG cells sensitizes the susceptibility to TFP-induced growth arrest through downregulation of cyclin D1. At present, it is not clear how Egr-1 downregulates cyclin D1 expression. Since inhibition of phosphoinositide 3-kinase (PI3K) inhibits the accumulation of cyclin D1 level (Oh et al., 2002), it is plausible to suggest that Egr-1 downstream target genes may deregulate the PI3K signal pathway. The identification of Egr-1 target genes which are associated with the downregulation of cyclin D1 remains to be determined.

In summary, this study demonstrates that TFPinduced elevation of Egr-1 contributes to TFP-mediated inhibition of cancer cell growth. We propose that restoration of Egr-1 function might be of value in treating some tumors in which Egr-1 gene is downregulated, such as breast cancer and glioma. 


\section{Acknowledgement}

This study was supported by a grant of the Korea Health 21 R\&D Project, Ministry of Health and Welfare, Republic of Korea (02-PJ1-PG3-20707-0001).

\section{References}

Cheung WY. Calmodulin plays a pivotal role in cellular regulation. Science 1980;4:19-27

Christy B, Nathans D. DNA-binding site of the growth factorinducible protein Zif268. Proc Natl Acad Sci USA 1989; 86:8737-41

Das A, Chendil D, Dey S, Mohiuddin M, Milbrandt J, Rangnekar VM, Ahmed MM. lonizing radiation down-regulates p53 protein in primary Egr-1-/- mouse embryonic fibroblast cells causing enhanced resistance to apoptosis. J Biol Chem 2001;276:3279-86

Gilman MZ, Wilson RN, Weinberg RA. Multiple proteinbinding sites in the 5 '-flanking region regulate $c$-fos expression. Mol Cell Biol 1986;6:4305-16

Hait WN, Lee GL. Characteristics of the cytotoxic effects of the phenothiazine class of calmodulin antagonists. Biochem Pharmacol 1985;15:3973-8

Hidaka $H$, Sasaki $Y$, Tanaka $T$, Endo $T$, Ohno $S$, Fujii $Y$, Nagata T. N-(6-aminohexyl)-5-chloro-1-naphthalenesulfonamide, a calmodulin antagonist, inhibits cell proliferation. Proc Natl Acad Sci USA 1981;78:4354-7

Huang RP, Adamson ED. A biological role for Egr-1 in cell survival following ultra-violet irradiation. Oncogene 1995;2: 467-75

Huang RP, Fan Y, de Belle I, Niemeyer C, Gottardis MM, Mercola D, Adamson E. Decreased Egr-1 expression in human, mouse and rat mammary cells and tissues correlates with tumor formation. Int J Cancer 1997;72:102-9

Kang UG Kim MJ, Suh PG, Ryu SH, Park JB, Kim JH, Kim YS, Lee YH. Inhibition of trifluoperazine-induced DNA fragmentation by cyclic AMP mediated signaling. Mol Cells 1999;31:596-602

Krones-Herzig A, Adamson ED, Mercola D. Early growth response 1 protein, an upstream gatekeeper of the p53 tumor suppressor, controls replicative senescence. Proc Natl Acad Sci USA 2003;100:3233-8

LeMaire $P$, Revelant $O$, Bravo R, Charnev $P$. Two mouse genes encoding potential transcription factors with identical DNA-binding domains are activated by growth factors in cultured cells. Proc Natl Acad Sci USA 1988;85:4691-5

Levin WJ, Press MF, Gaynor RB, Sukhatme VP, Boone TC, Reissmann PT, Figlin RA, Holmess EC, Souza LM, Slamon DJ. Expression patterns of immediate early transcription factors in human non-small cell lung cancer. Oncogene 1995; 11:1261-9

Lim RW, Varnum BC, Herschman HR. Cloning of tetradecanoyl phorbol ester-induced 'primary response' sequences and their expression in density-arrested Swiss 3T3 cells and a TPA non-proliferative variant. Oncogene 1987;1:263-70
Liu C, Adamson ED, Mercola D. Transcription factor EGR-1 suppresses the growth and transformation of human HT-1080 fibrosarcoma cells by induction of transforming growth factor $\beta 1$. Proc Natl Acad Sci USA 93 1996;93:11831-6

Liu C, Tao J, de Belle I, Huang RP, Adamson ED, Mercola D. The transcription factor EGR-1 suppresses transformation of human fibrosarcoma HT1080 cells by coordinated induction of transforming growth factor- $\beta 1$, fibronectin, and plasminogen activator inhibitor-1. J Biol Chem 1999;274: 4400-11

Lu KP, Means AR. Regulation of the cell cycle by calcium and calmodulin. Endocr Rev 1993;14:40-58

Means AR, Dedman JR. Calmodulin-an intracellular calcium receptor. Nature 1980;8:73-7

Milbrandt J. A nerve growth factor-induced gene encodes a possible transcriptional regulatory factor. Science 1987;238: 797-9

Nair P, Muthukkumar S, Sells SF, Han SS, Sukhatme VP, Rangnekar VM. Early growth response-1-dependent apoptosis is mediated by p53. J Biol Chem 1997;272:20131-8

Oh SY, Park KS, Kim JA, Choi KY. Differential modulation of zinc-stimulated p21 cip/Waf1 and cyclin D1 induction by inhibition of PI3 kinase in HT-29 colorectal cancer cells. Exp Mol Med 2002;34:27-31

Osborn M, Weber K. Damage of cellular functions by trifluoperazine, a calmodulin-specific drug. Exp Cell Res 1980;130: 484-8

Peroutka SJ, Snyder SH. Long-term antidepressant treatment decreases spiroperidol-labeled serotonin receptor binding. Science 1980;3:88-90

Schulman $\mathrm{H}$. The multifunctional $\mathrm{Ca}^{2+} /$ calmodulin-dependent protein kinases. Curr Opin Cell Biol 1993;5:247-53

Shin SY, Kim SY, Kim JH, Min DS, Ko J, Kang UG, Kim YS, Kwon TK, Han MY, Kim YH, Lee YH. Induction of early growth response-1 gene expression by calmodulin antagonist trifluoperazine through the activation of Elk-1 in human fibrosarcoma HT1080 cells. J Biol Chem 2001;16:7797-805

Shin SY, Ko J, Chang JS,. Min DS, Choi C, Bae SS, Kim MJ, Hyun DS, Kim JH, Han MY, Kim YH, Kim YS, Na DS, Suh PG, Lee $Y H$. Negative regulatory role of overexpression of PLCY1 in the expression of early growth response 1 gene in rat 3Y1 fibroblasts. FASEB J 2002a;16:1504-14

Shin SY, Yoon SC, Kim YH, Kim YS, Lee YH. Phosphorylation of glycogen synthase kinase- $3 \beta$ at serine- 9 by phospholipase $\mathrm{C} \gamma 1$ through protein kinase $\mathrm{C}$ in rat $3 Y_{1}$ fibroblasts. Exp Mol Med 2002b;34:444-50

Snyder SH. Stereoselective features of catecholamine dispostion and their behavioral implications. J Psychiatr Res 1974;11:31-9

Sukhatme VP, Cao X, Chang LC, Tsai-Morris C, Stamenkovich D, Ferreira PCP Cohe DR, Edwards SA, Shows TB, Curran T, Beau Le, Adamson ED. A zinc finger-encoding gene coregulated with $c$-fos during growth and differentiation, and after cellular depolarization. Cell 1988;53:37-43

Virolle T, Adamson ED, Baron V, Birle D, Mercola D, 
Mustelin T. The Egr-1 transcription factor directly activates PTEN during irradiation-induced signalling. Nat Cell Biol 3 2001;3:1124-8
Weiss B, Levin RM. Mechanism for selectively inhibiting the activation of cyclic nucleotide phosphodiesterase and adenylate cyclase by antipsychotic agents. Adv Cyclic Nucleotide Res 1978;9:285-303 